The Effect of Non-conventional Outbound Foreign Direct Investment (FDI) on the Domestic Employment of Multinational Enterprises (MNEs)

November 22, 2019

\author{
In Hyeock (Ian) Lee* \\ Department of Management \\ Quinlan School of Business, Loyola University Chicago \\ 16 E. Pearson St., Chicago, IL 60611 \\ Tel: (312) 915-7656 \\ Fax: (312) 915-6988 \\ E-mail: $\underline{\text { ilee1@luc.edu }}$ \\ Eunsuk Hong \\ Department of Financial and Management Studies \\ SOAS, University of London \\ Thornhaugh Street, Russell Square, London WC1H 0XG \\ Tel: (44) 2078984564 \\ Fax: (44) 2078984089 \\ E-mail: e.hong@soas.ac.uk \\ Shige Makino \\ Department of Management \\ The Chinese University of Hong Kong \\ Shatin, N.T., Hong Kong \\ Tel: (852) 3943-7636 \\ Fax: (852) 2603-5104 \\ E-mail: makino@baf.msmail.cuhk.edu.hk
}

${ }^{*}$ Corresponding author 


\title{
The Effect of Non-conventional Outbound Foreign Direct Investment (FDI) on the Domestic Employment of Multinational Enterprises (MNEs)
}

\begin{abstract}
Using a sample of 787 Japanese MNEs operating in 60 countries from 1996 to 2010, this study examines the impacts of MNEs' three most commonly observed forms of non-conventional outbound FDI (i.e., as a means to counter trade barriers, to achieve a financial hedge, or to obtain tax breaks) on domestic employment levels of MNEs at home. We build on a conceptual classification of 'motivation-activity’ of MNEs as a theoretical framework, and evaluate the impacts of MNEs' nonconventional outbound FDI on their domestic employment levels in relation to the MNEs' specific combination of 'motivation' and 'activity' as they conduct outbound FDI in host countries. The 3SLS regression results show strong evidence that non-conventional outbound FDI in core business activities reduces MNEs' domestic employment levels when the investment is primarily for responding to country-specific conditions, such as circumventing host country restrictions (e.g., FDI to counter trade barriers) or escaping from home country restrictions (e.g., FDI for tax incentive packages), while FDI in non-core business activities (e.g., FDI for financial hedging or FDI in tax havens) has either a positive or insignificant effect on MNEs’ domestic employment levels depending on whether it aims to develop FSAs or not. We conclude the study with public policy implications from these findings.
\end{abstract}

Keywords: Non-conventional outbound FDI, trade barriers, financial hedge, tax breaks, domestic employment, Japanese MNEs 


\section{Introduction}

Foreign direct investment (FDI) of multinational enterprises (MNEs) has been a key driver of the integration of global production and markets for the past several decades. The global outbound FDI flow increased from \$243 billion to \$1.01 trillion between 1990 and 2018 with the peak of \$1.68 trillion in 2015, and the global outbound FDI stock also skyrocketed from $\$ 559$ billion to $\$ 31$ trillion between 1980 and 2018 contributing to more than one-third of global GDP. (UNCTAD Statistics Data Center, https://unctadstat.unctad.org). Reflecting this serge of FDI in the global economy, numerous studies have examined MNEs' outbound FDI activities into foreign countries. They commonly find that MNEs are encouraged to conduct outbound FDI in overseas host countries to search for competitiveness-enhancing advantages such as (1) resources (e.g., natural resources, intermediary materials, lower-cost labor, etc.), (2) new markets (e.g., large emerging markets, customers with strong purchasing power, etc.), (3) strategic assets (e.g., scientific knowledge in upstream operations, marketing knowledge in downstream customers, etc.), and (4) efficiency (e.g., reduced manufacturing cost, enhanced productivity, etc.) (Dunning, 1998), all of which may be termed conventional outbound FDI. The common characteristics of the conventional outbound FDI is that it involves capital investment which is motivated to develop or accumulate firm-specific advantages (FSAs), either through asset seeking or acquisition, (i.e., ownership/internalization advantages), by setting up local operations that are linked to an MNE's business activities such as production, marketing and sales, and R\&D in host countries. (i.e., core business activities).

Although MNEs' outbound FDI activities have been studied extensively in the past years, an increasing number of MNEs have been reported to engage in outbound FDI as a means (1) to counter trade barriers (Urata, 1993; Dunning et al., 1996; Blonigen \& Feenstra, 1997; Deng, 2004), (2) to achieve a financial hedge (Pantzalis et al., 2001; Deng, 2004; Goldberg, 2004; Beugelsdijk et al., 2010), and/or (3) to obtain tax breaks (Deng, 2004; Goldberg, 2004; Desai et al., 2006; Clark, 2008; Dharmapala, 2008; Morck et al., 2008; Beugelsdijk et al., 2010). These forms of MNE activities can be considered FDI but are driven typically by protecting an MNE's current FSAs instead of creating 
new FSAs (i.e., a response to location specific conditions), and/or they engage in activities that are not directly related to an MNE's core business activities. (i.e., non-core business activities). These nonconventional forms of outbound FDI attempt to arbitrage country differences in international tax rates, tariff/non-tariff trade barriers, and/or expected financial returns/risks and foreign exchange rates across national borders as overseas location advantages.

MNEs seem to clearly benefit from non-conventional motivations for outbound FDI by either minimizing tax liabilities from foreign operations, preventing trade disputes with foreign countries with strong trade protectionism, or distributing potential foreign exchange-rate risks across multiple foreign countries with access to new capital markets therein. What remains unclear about nonconventional outbound FDI by MNEs is what economic impacts it may exert on MNEs' home economies. This research aims to fill this gap by investigating the impacts of MNEs' outbound FDI as a means (1) to counter trade barriers, (2) to achieve a financial hedge, and/or (3) to obtain tax breaks on the domestic employment levels hired by the MNEs at home using a sample of 17,788 subsidiaryyear cases from 787 Japanese MNEs in 1996-2010. As a way of evaluating the impact of nonconventional FDI on the home economy of MNEs, this study focuses on domestic employment levels hired by parent MNEs implementing such non-conventional FDI for the following two reasons. First, increasing domestic employment has traditionally been a central issue in general and to public policymakers who are in charge of enhancing social welfare in their economy. Second, the recent USChina trade disputes have facilitated the transfer of production and investment from China to ASEAN countries. While no official figures are available, it was reported that the US-China trade war has costed China almost 2 million industrial jobs from July, 2018 to May, 2019 by shifting Chinese MNEs’ outbound production to nearby ASEAN countries (South China Morning Post, 2019). Meanwhile, a recent study also reported that US firms' eliminating access to Puerto Rico for profitshifting led to lower investment and domestic employment in the U.S. (Suárez Serrato, 2018). These types of FDI are not driven by MNEs' traditional ownership advantages, which are considered as a necessary condition for FDI to take place in the conventional theory of FDI. These cases, however, 
show that non-conventional forms of FDI have critical impacts on domestic employment, which may affect economic growth and social stability in a home country of MNEs conducting non-conventional FDI. In fact, there have been consistent calls for empirical research that examines MNE heterogeneity to assess the impact of MNE operations on the employment levels of MNEs at home (Harrison \& McMillan, 2007; Debaere et al., 2010). In particular, some scholars have raised concerns about current MNE practices of using outbound FDI for various non-conventional motives such as to get tax breaks in tax havens (Slemrod \& Wilson, 2009; Dharmapala, 2008) as part of their internationalization strategy. To the best of our knowledge, this study is one of the first that presents empirical evidence on the relationship between non-conventional outbound FDI and the domestic employment levels of MNEs at a firm level.

This study aims to contribute to the literature in two major areas. First, it suggests theoretical channels that uncover the hidden relationships between the emerging non-conventional outbound FDI and MNEs' domestic employment levels at home. For this purpose, we develop a conceptual framework to classify conventional FDI and different types of non-conventional FDI, based on the nexus of 'motivation' and 'activity' of MNEs. In this framework, we identify three non-conventional outbound FDI, i.e., FDIs formed as a means to overcome trade barriers, unexpected fluctuations in currency exchange rates, or high domestic tax rates. Second, it evaluates empirically whether such non-conventional forms of outbound FDI are beneficial or detrimental or irrelevant to the MNEs' home countries in terms of their impacts on domestic employment. We believe this study provides important implications to public policymakers, because increasing domestic employment is a central issue to economic growth and social welfare in an economy.

\section{Literature Review}

Insert Figure 1 about here 
For comprehensive and focused literature reviews on FDI and its effects, we utilize Figure 1. The vertical axis in Figure 1 indicates two types of FDI which MNEs may conduct across national borders, i.e., (1) conventional types of FDI that include (natural) resource-seeking, market-seeking, strategic asset-seeking, and efficiency-seeking FDI (Dunning, 1998) and (2) non-conventional types of FDI such as FDI to counter trade barriers (Deng, 2004), FDI for financial hedge (Goldberg, 2004), and FDI to exploit tax breaks (Clark, 2008). The horizontal axis in the same figure, on the other hand, represents 'host-country effects' (i.e., the effects of FDI on firms and the economy in a host country) and 'home-country effects' (i.e., the effects of FDI on firms and the economy in a home country).

In Cell I, MNEs conduct FDI in search for conventional types of country-specific resources by bringing their firm-specific resources and capabilities abroad, and, as a result, such FDI by MNEs generally exerts positive effects on the economy of host countries where sophisticated MNEs equipped with advanced FSAs are accommodated through their location selection. Abundant studies have investigated these host-country effects of FDI by MNEs in terms of indigenous firms' enhanced performance through productivity spillovers from foreign investors (Haddad \& Harrison, 1993; Aitken \& Harrison, 1999; Görg \& Greenway, 2004; Buckley, Clegg \& Wang, 2006, 2007; Haskel, Pereira \& Slaughter, 2007; Vahter \& Masso, 2007; Altomonte \& Pennings, 2009; Motohashi \& Yuan, 2010), net entry of new indigenous firms and their survival spurred by foreign firms (Görg \& Strobl, 2002; De Backer \& Sleuwaegen, 2003; Burke, Görg \& Hanley, 2008; Barbosa \& Eiriz, 2009; Ayyagari \& Kosová, 2010), and domestic entrepreneurship by local entrepreneurs in proximity to nearby MNEs from a geographic perspective (Lee, Hong \& Sun, 2014; Sun, Lee \& Hong, 2017) among others. Regarding the employment effects of FDI in the labor market of host countries, most studies reported positive effects on host-country employment (Almeida, 2007; Dinga \& Mnich, 2010; Peluffo, 2015; Sune et al., 2009; Waldkirch \& Nunnenkamp, 2009) with a few exceptions reporting negative effects between the two constructs (Hijzen et al., 2013; Jude \& Silaghi, 2015).

In Cell II, on the other hand, as MNEs implement FDI in search for conventional types of country-specific advantages abroad, such FDI implemented by MNEs in foreign countries may also 
exert substantial effects on the economy of home countries where the MNEs are headquartered due to the interconnected nature between trade and FDI of MNEs. As such, some studies tackled with homecountry effects of FDI by MNEs with particular focuses on changes in the home-country exports after MNEs' outward FDI (Kokko, 2002, 2006) and heterogeneous productivity spillovers that took place therein (Vahter \& Masso, 2007; Tang \& Altshuler, 2015). In addition, it should be noted that abundant studies have explored the impact of FDI on home-country employment for the past decades, reflecting common concerns on FDI that may hollow domestic job opportunities by transferring domestic production process abroad. Using country-level data on FDI, trade, and employment, some studies estimated empirically a substitutable negative relationship between FDI and home-country employment (Becker et al., 2005; Kokko, 2006), but other studies showed a complementary positive relationship between the two constructs (Agarwal, 1996, 1997; Hijzen, Inui \& Todo, 2007; Becker \& Muendler, 2008; Federico \& Minerva, 2008; Masso, Varblane \& Vahter, 2008; Desai, Foley \& Hines Jr., 2009; Liu \& Lu, 2009; Cuyvers \& Soeng, 2011). However, a lot of studies also reported mixed and inconclusive results on the relationship between FDI and home-country employment levels, which are contingent on diverse firm-, labor-, industry-, or country-specific attributes (Altzinger \& Bellak, 1999; Mariotti, Mutinelli \& Piscitello, 2003; Chen \& Ku, 2005; Konigs \& Murphy, 2006; Harrison \& McMillan, 2007; Molnar, Pain \& Taglioni, 2007, 2008; Debaere, Lee \& Lee, 2010; Mitra \& Ranjan, 2010; Hijzen, Jean \& Mayer, 2011; Driffield, Pereira \& Temouri, 2017). Using firm-level data on MNEs’ FDI, overseas subsidiaries established, and parent employment levels, a recent study elaborated that the relationship between the two depends on the specific motivations of FDI revealed by MNEs (Hong, Lee \& Makino, 2018).

As can be seen from Figure 1, most extant studies focus on either host-country effects (Cell I) or home-country effects (Cell II) of conventional forms of FDI. Only a handful of studies look into non-conventional forms of FDI: however, these studies typically focus on identifying country-specific factors in host countries that spur non-conventional FDI (Cell III). For example, recent studies initiated empirical investigations on the tax haven FDI of MNEs headquartered in either OECD 
countries (Jones \& Temouri, 2016) or emerging economies (Chari \& Acikgoz, 2016) under the name of escapism FDI (Stoian \& Mohr, 2016; Kottaridi, Giakoulas \& Manolopoulos, 2019). These studies, however, focus primarily on uncovering the main drivers of such non-conventional FDI in tax havens rather than its consequences or outcomes in the host countries. Unlike the case of conventional FDI in Cell II, the impact of non-conventional FDI on domestic economy, especially in terms of homecountry employment, has not been systematically investigated yet, representing a knowledge gap in the literature (Cell IV).

\section{Conceptual Framework and Hypotheses Development}

\subsection{Conventional vs. Non-conventional Outbound FDI}

Insert Figure 2 about here

Conventional versus non-conventional outbound FDI are distinguished in terms of two dimensions with which MNEs conduct overseas business using their capital injected into foreign countries: (1) motivations of MNEs for conducting outbound FDI and (2) activities that MNEs implement in host countries through outbound FDI. The ‘motivation' represents what MNEs intend to do as they internationalize into host countries, and it indicates whether MNEs intend to 'develop or accumulate new FSAs' or to just 'protect existing FSAs' using the capital transferred in host countries. The 'activity' represents what the MNEs actually do in the host countries, and it indicates whether MNEs conduct overseas activities in 'core' or 'non-core' business in host countries using the capital from their home markets. The key argument is that the conventional forms of outbound FDI are motivated to upgrade FSAs from direct investment abroad and engaged in MNEs' value added activities in core business, whereas the non-conventional forms of outbound FDI do not satisfy either (or both) of them. ${ }^{1}$

\footnotetext{
${ }^{1}$ As such, it is assumed implicitly that there is little connection between conventional FDI and non-conventional FDI ex ante.
} 
As captured in Figure 2(a), conventional types of outbound FDI are defined as MNEs' transfer of capital to a host country where they engage in overseas activities related to their core business and intended to develop or accumulate new FSAs from these core activities in the form of the MNEs' FSA upgrade. The key condition of conventional outbound FDI is that it involves 'core business activities' in a host country, which are intended to create certain forms of 'FSA upgrade' to the MNEs (e.g., increased revenues, cost reductions, enhanced efficiency, reputation, acquired knowhow, etc.). As such, Dunning's (1998) classifications of outbound FDI (i.e., market-, labor-, resource-, strategic-asset seeking FDI) belong to this conventional category of FDI using MNEs' location advantages in their foreign operations.

On the other hand, non-conventional types of outbound FDI do not satisfy either (or both) of these characteristics. In other words, non-conventional outbound FDI projects are used either to achieve efficiency in their 'non-core businesses' (e.g., financial management of expected risks/uncertainties and foreign exchange rates, and tax-saving management using zero or minimum corporate tax rates in tax havens) or to circumvent regulatory obstacles or barriers that may limit the opportunity for MNEs to 'protect existing FSAs' from their core or non-core businesses in foreign countries (e.g., tariff/non-tariff barriers on trade and trans-border differences of incentive packages in tax rates). As captured in Figure 2(b), non-conventional forms of outbound FDI are spurred by MNEs' motivations to arbitrage potential risks or liabilities from their foreign operations, and they include three types: (1) outbound FDI aimed to reduce trade barriers with major exporting markets by arbitraging international political risks therein or outbound FDI aimed to exploit preferential tax incentive packages for foreign investors that are offered by host country governments, both of which help MNEs keep protecting FSAs from core businesses through the physical operations of their foreign subsidiaries established in host countries [i.e., Figure 2(b)(i)]; (2) outbound FDI for financial hedges to diversify international financial risks/uncertainties from foreign exchange rate fluctuations across multiple countries, which help MNEs develop or accumulate FSAs in financial transactions that can arise independently from transactions accruing from their core businesses [i.e., Figure 
2(b)(ii)]; and (3) outbound FDI aimed to exploit zero or minimum corporate tax rates in tax haven countries by arbitraging differences in tax liabilities across national borders, which help MNEs protect their FSAs while minimizing tax payments, but it does not contribute to MNEs’ core manufacturing and/or service businesses [i.e., Figure 2(b)(iii)].

\subsection{Non-conventional FDI and Employment in MNEs' Home countries}

Insert Figure 3 about here

In developing hypotheses on the relationship between non-conventional outbound FDI and domestic employment of MNEs at home, we formalize the aforementioned ‘motivation-activity' nexus of MNE internationalization and strategy as in Figure 3. In Figure 3, it should be noted that the motivations of MNEs intended for conducting outbound FDI (i.e., ownership/internalization advantages versus responses to location-specific conditions) and the activities that MNEs actually implement in host countries (i.e., core versus non-core business activities) signify potential channels between the nonconventional outbound FDI and domestic employment of MNEs at home.

The concept of 'Ownership/Internalization Advantages' as the motivation of outbound FDI is based on MNEs' FSA development and accumulation in either core or non-core business activities. Such FSAs are not easily imitable by outsiders, because MNEs commonly internalize them as a part of their organizations using strict internal controls. Therefore, MNEs' internalized key FSAs can act as effective isolating mechanisms (Rumelt, 1984) generating casual ambiguity between the FSAs and outcomes of MNEs as well as requesting the MNEs to secure more employees at home to manage them across national borders. ${ }^{2}$ The other concept of 'Responses to Location-specific Conditions' is based on MNEs' FSA protection in host countries to evade potential trade frictions, to utilize host

\footnotetext{
${ }^{2}$ Firms' generation of effective 'isolating mechanisms' is to exploit 'imitation barriers' to and 'uniqueness' of the firms' key resources and capabilities by creating 'casual ambiguity' between firm actions and outcomes (Lippman \& Rumelt, 1982; Rumelt, 1984). Thus, effective isolating mechanisms can make it difficult for outsiders to recognize and replicate the main sources of superior firm outcomes in the market, and firms may need to secure additional resources (including human resources) for operating the effective isolating mechanisms in the market.
} 
country governments' favorable tax incentive programs, or to arbitrate zero corporate tax rates in either core or non-core business activities. Such FSAs are easily imitable by outsiders, because a list of extant tariff and non-tariff trade barriers, diverse tax breaks for foreign investors, and current corporate tax rates in different foreign countries is publicly and readily available to all interested MNEs, who can decide on making direct investment plans in those foreign countries to utilize some or all of such threats or opportunities to their business advantages therein. As such, MNEs' utilization of such external public information on country-specific conditions cannot act as effective isolating mechanisms (Rumelt, 1984), and, as a result, it does not necessarily request the MNEs to secure more human resources at home to operate them effectively.

Our key argument is that outbound FDI may have a positive impact on domestic employment when it embarks on developing or accumulating FSAs to an MNE as a whole: however, when outbound FDI is confined to protecting an MNE's FSAs with core business activities moved to host countries, it could have a negative impact on domestic employment. On this basis, we propose the following two general propositions. First, outbound FDI intended for generating ownership/ internalization advantages is more likely to increase domestic employment, as compared to outbound FDI intended for responding to location-specific conditions. Second, MNE activities engaged in core business tend to have a substantial impact on the MNE's generation of ownership/internalization advantages, leading to a higher likelihood to increase domestic employment: as such, outbound FDI with core business activities moved to host countries is likely to reduce domestic employment of MNEs at home. Therefore, the final impacts of MNEs' non-conventional outbound FDI on their domestic employment at home should be evaluated in relation to the MNEs' specific combination of 'motivation' and 'activity' as they conduct outbound FDI in host countries.

\subsubsection{Outbound FDI, Trade Barriers, and Domestic Employment of MNEs}

Modern theories of MNEs predict that MNEs commonly aim to exploit, transfer, and replicate their domestically developed firm-specific advantages (FSAs) in foreign markets (Hymer, 1976; Rugman, 
1981; Rugman et al., 2011), resulting in their choice of 'trade' as the most efficient and optimal type of entry modes in their internationalization process (Hennart, 1982, 2009). Under diverse tariff and non-tariff trade barriers, MNEs are subject to the threats of potential protectionism from their major exporting markets, and such threats of protectionism often prompt MNEs to switch their entry mode from trade to 'outbound FDI’ (Buckley \& Casson, 1976; Rugman, 1981; Rugman et al., 2011; Hennart, 1982, 2009). This phenomenon is apparent with the emergence of regional trade and investment blocs with trade barriers removed for bloc insiders such as NAFTA and EU members; many MNEs establish foreign subsidiaries within the regional blocs to maintain their current access to these integrated regional markets (Buckley et al., 2003; Deng, 2004; Rugman \& Verbeke, 2004; Verbeke \& Kano, 2016).

Outbound FDI aimed to remove such tariff and non-tariff trade barriers are typically characterized as responding to legal and regulatory location-specific conditions in a host country, because the primary motivation is not to develop new FSAs but to protect existing FSAs by removing the threat of protectionism in the host country (Urata, 1993; Dunning et al., 1996; Blonigen \& Feenstra, 1997). In addition, its nature of investment is to prevent potential risks from taking place, because MNEs often consider replacing trade with outbound FDI to remove any international political risks accruing to trade barriers with the host country of their major export markets. When MNEs conduct outbound FDI to circumvent potential trade barriers in host countries with strong protectionism, it is readily imitable by other competitors, not acting as effective isolating mechanisms (Rumelt, 1984). In addition, it is commonly accompanied by replacing their current domestic production operations with new foreign production facilities established in host countries to be effectively integrated into the foreign countries, which could result in the reduction of domestic employment in the home countries of these MNEs.

Hypothesis 1: Outbound FDI used to counter trade barriers will negatively relate to the domestic employment levels of MNEs. 


\subsubsection{Outbound FDI, Financial Hedge, and Domestic Employment of MNEs}

Financial resources are a tangible form of FSAs that MNEs need to expand their markets and operations abroad (Rugman, 1981, 2005). MNEs are often subject to unpredictable and limited access to financial resources because they are involved in trans-border transactions governed by different economic and monetary systems based on the country and region of their overseas operations. Under fluctuating foreign exchange rates and the unequal distribution of capital resources across national borders, some MNEs choose to conduct outbound FDI to minimize potential transaction costs of overseas operations in multiple host countries (Hennart, 1982, 2009). The international market diversification aimed to spread risks and uncertainties in foreign operations has been a traditional explanation for the birth and proliferation of MNEs (Rugman, 1981; Deng, 2004). Dunning et al. (1996) explain the impetus for the new wave of MNEs’ outbound FDI back in the 1990s using an investment development path (IDP). They argue that conventional, mature-stage MNEs (i.e., stages 4 and 5 in the IDP) may seek further efficiency advantages by exploiting national difference of access to capital markets in addition to diversifying their investments in foreign countries. MNEs are likely to benefit from outbound FDI for both types of financial hedges when they establish a broader network of foreign subsidiaries across multiple foreign countries (Pantzalis et al., 2001).

As such, outbound FDI used as a financial hedge is commonly motivated by MNEs' arbitrage of risks either to spread potential financial risks and uncertainties from foreign exchange rate fluctuations (Rugman, 1981; Deng, 2004) or to obtain access to capital resources in foreign countries (Dunning et al., 1996). Although both belong to the functional and non-core businesses of MNEs, outbound FDI as a financial hedge is aimed to embark upon MNEs' developing or accumulating new FSAs by exploiting a broad network of foreign subsidiaries that enable the MNEs to manage mobilizing scarce but valuable financial resources across national borders. Such key FSAs in financial management are likely to act as isolating mechanisms with casual ambiguity between the FSAs and outcomes of MNEs (Rumelt, 1984), encouraging the MNEs to hire more employees at home to 
manage them effectively across national borders. In other words, MNEs that use outbound FDI as a financial hedge require proactive cross-national financial management using 'regular' business channels to strengthen their financial resource foundations, which in turn helps them expand their financial functions, often resulting in increased domestic employment levels at the headquarters in the MNEs' home nations.

Hypothesis 2: Outbound FDI used as a financial hedge will positively relate to the domestic employment levels of MNEs.

\subsubsection{Outbound FDI, Tax Liabilities, and Domestic Employment of MNEs}

Tax planning to minimize home and host-country tax payments is becoming a common strategy of MNEs when making FDI decisions (Deng, 2004; Goldberg, 2004; Desai et al., 2006; Clark, 2008; Dharmapala, 2008; Morck et al., 2008). Tax planning is aimed to arbitrage the national differences in tax rates and systems with an aim to reduce tax liabilities from foreign operations. MNEs have used two primary ways to reduce tax expenditures from their international businesses, and outbound FDI that MNEs employ for tax breaks using both approaches involves arbitrage of potential liabilities to minimize tax expenditures.

The first way for MNEs to employ tax breaks is to engage in outbound FDI in foreign countries that offer preferential tax incentives to foreign investors (Deng, 2004). In this first approach, host countries engage in aggressive competition to attract capable foreign investors to their national borders so that they can utilize potential knowledge spillovers from sophisticated MNEs to upgrade their own indigenous firms and boost their domestic economies (OECD, 2002). For this purpose, many host country governments have provided foreign investors with preferential tax incentive packages that help MNEs minimize taxes by relocating their home country operations to those host countries. It should be noted that, in the first approach utilizing preferential tax incentive packages from host countries, MNEs may keep protecting existing FSAs from their core businesses in the host 
countries, because MNEs' core physical production/service facilities must be relocated to the foreign host countries to receive the full tax incentive benefits. However, outbound FDI for preferential tax incentive packages is to circumvent tax-related obstacles or barriers in the home country that may limit the opportunity for MNEs to protect their FSAs, by responding to the legal and regulatory location-specific conditions provided in the host countries. As such, outbound FDI for utilizing preferential tax incentive packages in foreign host countries may result in reduced domestic employment by the parent MNEs at home, because such tax incentives prompt MNEs to shift their production base from home to the host country without adding any effective isolating mechanisms to the MNEs. In addition, such an outbound FDI may create opportunity costs, or the risks of missing opportunities to gain returns from investments in their core businesses.

On the other hand, the second way for MNEs to use tax breaks is to establish foreign subsidiaries that are indirectly held through a tax haven subsidiary (Clark, 2008). In this second approach, some foreign-country tax regimes allow MNEs to simply finance the MNEs's subsidiaries in tax havens encouraging tax-minimizing behaviors across national borders (Dharmapala, 2008).

Therefore, MNEs may be eager to transfer tax liabilities to tax havens that provide foreign investors with zero or minimum corporate tax rates/withholding tax rates (Desai et al., 2006; Dharmapala, 2008), and such tax havens have consequently accommodated a disproportionate share of the world FDI (Dharmapala, 2008; Slemrod \& Wilson, 2009). It should be noted that, in the second approach where MNEs make direct investments in foreign-country tax havens by simply financing their own subsidiaries, they may not act as effective isolating mechanisms with casual ambiguity to their core manufacturing and/or service businesses, because MNEs simply set up subsidiaries on paper, which involve transfer pricing and reallocation of debt among affiliates (Dharmapala, 2008). As a result, it is likely that outbound FDI seeking tax breaks in ‘tax haven’ countries may not affect the MNEs’ employment levels at home, because such investment is usually made through 'paper companies,' which do not develop nor accumulate any FSAs through core business operations that can require hiring additional employees in the MNEs' home country as posited in H3(b). 
Hypothesis 3(a): Outbound FDI seeking a preferential tax incentive package in non-tax haven countries will negatively relate to the domestic employment levels of MNEs.

Hypothesis 3(b): Outbound FDI seeking tax breaks in tax haven countries will not significantly relate to the domestic employment levels of MNEs.

\section{Research Design}

\subsection{Data and Sample}

The primary data sources for this study include the foreign subsidiaries of Japanese MNEs derived from the Toyo Keizai database built from questionnaire surveys and telephone interviews of managers at Japanese overseas subsidiaries, in addition to the annual reports and media releases of the subsidiaries. The Toyo Keizai dataset provides arguably the best available information on Japanese MNEs and their subsidiaries. This dataset contains a wide range of subsidiary-level information on Japanese MNEs, including the purposes for overseas establishments and other basic financial indices. The comprehensiveness and accuracy of this dataset has been acknowledged in previous empirical studies (e.g., Beamish, Delios, \& Makino, 2001). Data on Japanese parent MNEs is extracted from the NIKKEI Economic Electronic Databank System (NEEDS) published by Japan’s Ministry of Economy, Trade \& Industry (METI).

We follow three steps in choosing a sample for this study. First, we exclude from the primary data all Japanese overseas subsidiaries established by two or more parent MNEs to control for potential confounding effects of FDI undertaken by multiple parent MNEs. Second, we also exclude from the primary data all foreign subsidiaries with less than 10 percent of Japanese parent MNEs' equity ownership in their overseas subsidiaries to avoid misleading estimations caused by MNEs' lack of ownership control in their overseas subsidiaries. Third, the study period is from 1996-2010 because we had access to the Toyo Keizie database until 2010, while the questionnaire surveys for the 
reasons why Japanese MNEs established foreign subsidiaries are inconsistent until 1995. Our final dataset includes a sample of 4,447 subsidiaries established by 787 Japanese parent companies operating in 60 countries over 1996-2010, amounting to 17,788 subsidiary-year cases.

\subsection{Dependent and Independent Variables}

In this study, the logged number of domestic employees in a Japanese parent MNE $p$ at time $t\left(E M P_{p t}\right)$ is the main dependent variable. To address the potential endogeneity of foreign subsidiary employment when estimating the main impact of outbound FDI motivation on the MNEs' domestic employment, the size of each subsidiary measured by the logged number of employees working for an MNE's foreign subsidiary $s$ at time $t\left(E M P_{s t}\right)$ is used as the secondary dependent variable (Gomes \& Sanchez, 2005; Fenton-O’Creevy et al., 2008).

For independent variables, we utilize the Toyo Keizai database's 15 classifications $^{3}$ of Japanese outbound FDI motivations (M1-M15) per each subsidiary-year case. Among these motivations, we use (1) measures to counter trade barriers (M1); (2) financing, currency hedging (M2); and (3) tax breaks for investment (M3) as independent dummy variables, reflecting the Japanese MNEs' non-conventional FDI motivations. To distinguish between different types of outbound FDI for tax breaks, we split the investment dummy for tax breaks (M3) into two groups: one for exploiting preferential tax-incentive packages in host countries $\left(M 3_{\text {Non-tax havens }}\right)$ and the other for establishing paper companies in tax-haven countries $\left(M 3_{\text {Tax havens }}\right)$. We use the list of tax-haven

\footnotetext{
${ }^{3}$ The 15 motivation dummies are (1) M1. Measures against trade barriers; (2) M2. Financing, currency hedging; (3) M3. Tax breaks for investment; (4) M4. Seeking resources and materials; (5) M5. Labor seeking; (6) M6. Construction of international networks of production; (7) M7. Construction of international networks of distribution; (8) M8. Local market expansion; (9) M9. Exports to other countries; (10) M10. Reverse imports to Japan; (11) M11. Follow customers, suppliers and related companies; (12) M12. Collection of information, knowledge seeking, royalty; (13) M13. Research, development, product planning; (14) M14. Expansion into new business; (15) M15. Strengthening of regional headquarters function.
} 
countries reported by the Financial Stability Forum (FSF), International Monetary Fund (IMF), and World Bank (WB) in 2000. ${ }^{4}$

\subsection{Control Variables}

Our conceptual framework captured in Figures 2 and 3 indicates that MNEs' domestic employment is determined not only by their FDI motivations, but also by firm-specific (parent and subsidiary) and country-specific (home and host) factors. Thus, we include a set of parent-firm-, foreign-subsidiary-, home-country- and host-country-specific variables to control for other major determinants of employment and FDI levels that are both theoretically and empirically verified in the previous literature.

Two variables are used for capturing parent-firm-specific characteristics. First, we control for the innovative capabilities of parent MNEs measured by parent R\&D intensities which are calculated by dividing R\&D expenses by operating revenues in the parent MNE $p$ at time $t\left(I C_{p t}\right)$. The parent MNEs' innovation capacity is one of the important sources of knowledge for their subsidiaries within the intra-corporate knowledge transfer network of MNEs (Fang et al., 2010; Berry, 2015). Moreover, parent MNEs’ R\&D intensity controls for the home base-exploiting versus home base-augmenting R\&D activities (Kuemmerle, 1997) which may affect the domestic employment of R\&D personnel at home. Second, we control for the strength of the Japanese MNEs' foreign local networks measured by the number of overseas subsidiaries established by each Japanese MNE in each host country $h$ in a given year $t\left(N E T_{h t}\right)$. It has been widely confirmed that MNEs with prior experience in a host country provide them with flexibility in managing their foreign subsidiaries using accumulated information about the local environment from the local networks of subsidiaries compared to first-time entrants (Delios \& Beamish, 2001; Fang et al., 2010; Arslan \& Dikova, 2015).

\footnotetext{
${ }^{4}$ The tax haven countries on the list of FSF-IMF-WB (2000) include Andorra, Anguilla, Antigua \& Barbuda, Aruba, Bahamas, Bahrain, Barbados, Belize, Bermuda, British Virgin Islands, Cayman Islands, Cook Islands, Costa Rica, Cyprus, Dominica, Gibraltar, Grenada, Guernsey, Sark \& Alderney, Hong Kong, Ireland, Isle of Man, Jersey, Lebanon, Liechtenstein, Luxembourg, Macao, Malta, Marshall Islands, Mauritius, Monaco, Montserrat, Nauru, Netherlands Antilles, Niue, Palau, Panama, Saint Kitts \& Nevis, Saint Lucia, Saint Vincent \& the Grenadines, Samoa, Seychelles, Singapore, Switzerland, Turks \& Caicos Islands, and Vanuatu.
} 
In terms of foreign-subsidiary-specific characteristics, we use the logged amount of revenue of a foreign subsidiary s at time $t\left(S A L E S_{s t}\right)$ to control for each subsidiary's performance (Chan et al., 2008; Fang et al., 2010).

Two variables are used for addressing home-country-specific characteristics. First, we control for the sectoral composition of the Japanese economy during our study period by measuring the ratio of Japanese GDP by industry $i$ over 22 sectors $^{5}$ at time $t\left(S C_{i t}\right)$ (Dekle, 2002). Second, we control for Japan's economic health during our study period by measuring annual unemployment rates in Japan at time $t\left(U E M P_{j t}\right)$, which is widely recognized as an important indicator of economic and business fluctuations (Martin \& Rogers, 2000).

Three variables capture host-country-specific characteristics. First, we control for the market size of each host country measured by the logged GDP of a host country $h$, in which a Japanese MNE invests at time $t\left(G D P_{h t}\right)$. The market size of a host country provides investment opportunities to MNEs which look for new markets or seek to maximize returns on their investments through the efficient utilization of resources and exploitation of economies of scale (Moosa \& Cardak, 2006; Uddin \& Boateng, 2011). Second, we use the measure of 'rule of law' in the Worldwide Governance Indicators (WGI) constructed by the World Bank ${ }^{6}$ to control for the effectiveness of legal institutions in a host country $h$, in which Japanese MNEs invest at time $t\left(R o L_{h t}\right)$. An effective legal system is recognized as one of the key factors in making and sustaining competitive advantage for any foreign investors seeking country-specific advantages in host countries, because a host country with wellestablished legal systems and institutions provides a high level of respect for and protection of intellectual property rights and the functioning of agencies for the enforcement of law (Pajunen, 2008; Buchanan et al., 2012; Wang et al., 2012). Third, transportation and transaction costs between

\footnotetext{
${ }^{5}$ The 22 industries are agriculture, forestry and fishing; mining; food products and beverages; textiles; pulp, paper and paper products; chemicals; petroleum and coal products; non-metallic mineral products; iron and steel; fabricated metal products; machinery; electrical machinery, equipment and supplies; transport equipment; precision instruments; manufacturing others; construction; electricity, gas and water supply; wholesale and retail trade; finance and insurance; real estate; transport and communications; and service activities.

${ }^{6}$ The 'rule of law' indicator has a spread of -2.5 (i.e., low rule of law) to 2.5 (i.e., high rule of law).
} 
headquarters and foreign subsidiaries are captured by the geographic distance between Japan and a Japanese MNE's host economy, which is measured as the great-circle distance in km between the capital city of Japan and that of each host country $h$, using longitude and latitude coordinates $\left(D I S_{j h}\right)$. Distance can play an ambiguous role for FDI: on the one hand, distance can be an impediment to FDI, as managerial and transaction costs normally increase with distance; but, on the other hand, distance can be an incentive for FDI, as foreign direct production in a host country can avoid transportation costs and trade barriers (Borrmann et al., 2005).

We construct the above control variables using data from the NIKKEI Economic Electronic Databank System for $I C_{p t}$, from the Toyo Keizai data for $N E T_{h t}$ and $S A L E S_{s t}$, from the Japan Statistical Yearbook for $S C_{i t}$ and $U E M P_{j t}$, from the World Economic Outlook Database of the International Monetary Fund for $G D P_{h t}$, and from the World Bank’s Worldwide Governance Indicators for $R o L_{h t}$.

Since outbound FDI projects may have various investment motivations, and are implemented across various industrial sectors and host regions over the sample period of 15 years, we also control for the remaining 12 conventional FDI motivations ( $\left.M_{\text {Conventional }}\right)$, the heterogeneous industries of Japanese parent MNEs $\left(\alpha_{i}\right)$, regional dummies of host countries $\left(\alpha_{r}\right)^{7}$, and yearly dummies $\left(\alpha_{t}\right)$ in the subsequent empirical estimations.

\subsection{Econometric Model}

Our econometric model for testing Hypotheses $1-3$ is specified as follows.

$$
\begin{aligned}
E M P_{p t} & =\beta_{0}+\beta_{1} M 1+\beta_{2} M 2+\beta_{3} M 3_{\text {Non-tax havens }}+\beta_{4} M 3_{\text {Tax havens }}+\beta_{5} E M P_{s t} \\
& +\beta_{6} G D P_{h t}+\beta_{7} S C_{i t}+\beta_{8} U E M P_{j t}+\beta_{9} D I S_{j h}+\beta_{10} R o L_{h t}+\beta_{11} N E T_{h t}+\beta_{12} I C_{p t} \\
& +M_{\text {Conventional }}+\alpha_{i}+\alpha_{r}+\alpha_{t}+\epsilon_{p, s, h, i, r, t}
\end{aligned}
$$

(1)

\footnotetext{
${ }^{7}$ Host countries are categorized into seven regional dummies: Asia, Middle East, Europe, North America, Latin America, Africa, and Oceania.
} 
where $\epsilon_{p, s, h, i, r, t}$ is an error term.

One of the key considerations in selecting the most appropriate econometric model for this study is to control for potential simultaneous causality between employment levels of Japanese MNEs at home $\left(E M P_{p t}\right)$ and their overseas subsidiaries in host countries $\left(E M P_{s t}\right)$ in equation (1). Intuitively, some MNEs may make simultaneous decisions on the employment levels both at headquarters and at foreign subsidiaries in host countries when implementing outbound FDI projects to achieve an optimal allocation of human resources across national boundaries. As such, the employment level of foreign subsidiaries in host countries may be determined endogenously in the model by the employment level of parent MNEs at home. To deal with this endogeneity issue in our regressions, we specify the second equation for the determinants of employment in foreign subsidiaries $\left(E M P_{s t}\right)$ to obtain an instrumental variable for the endogenous employment levels of foreign subsidiaries:

$$
\begin{aligned}
E M P_{s t} & =\beta_{0}+\beta_{1} M 1+\beta_{2} M 2+\beta_{3} M 3_{N o n-t a x \text { havens }}+\beta_{4} M 3_{\text {Tax havens }}+\beta_{5} E M P_{p t} \\
& +\beta_{6} G D P_{h t}+\beta_{7} S C_{i t}+\beta_{8} U E M P_{j t}+\beta_{9} D I S_{j h}+\beta_{10} R o L_{h t}+\beta_{11} N E T_{h t}+\beta_{12} S A L E S_{s t} \\
& +M_{\text {Conventional }}+\alpha_{i}+\alpha_{r}+\alpha_{t}+\epsilon_{p, s, h, i, r, t}
\end{aligned}
$$

To address the endogeneity of $E M P_{p t}$ and $E M P_{s t}$, we utilize a simultaneous equations model (SEM) with a system of equations (1) and (2), and then estimate the system using three-stage least squares (3SLS) regressions. By combining instrumental variable (IV) techniques and generalized least square (GLS) estimators, the 3SLS regressions are capable of achieving consistency and efficiency, and correcting for the correlation between the disturbances across equations (1) and (2) in the system (Greene, 2008). To satisfy the order condition for identification in the 3SLS estimation, we exclusively include the innovative capacity of parent MNEs $\left(I C_{p t}\right)$ in equation (1) and the sales performance of foreign subsidiaries $\left(S A L E S_{s t}\right)$ in equation (2), assuming $I C_{p t}$ will have a direct impact on parent MNEs' domestic employment ( $E M P_{p t}$ ), but only an indirect impact on the employment level of their foreign subsidiaries $\left(E M P_{s t}\right)$. Correspondingly, we assume that $S A L E S_{s t}$ in 
equation (2) will have a direct impact on the employment level of overseas subsidiaries $\left(E M P_{s t}\right)$, but only an indirect impact on domestic employment by their parent MNEs ( $\left.E M P_{p t}\right)$.

\section{Results}

Insert Tables 1- 3 about here

Table 1 provides the descriptive statistics and pairwise correlations for all the variables used in our regression analyses. The maximum variance inflation factor (VIF) value of the variables in Table 1 is 2.76 that is less than the popularly accepted critical value of 5 (e.g., Rogerson, 2001) in the literature, confirming that the interpretation of our results is not affected by multicollinearity. Table 2 displays our 3SLS regression results on the relationship between non-conventional types of Japanese MNEs' outbound FDI and their domestic employment levels. To increase the reliability of the estimates, we run separate 3SLS regressions with three models: Models 1 and 2 include $M 3_{\text {Non-tax havens }}$ and $M 3_{\text {Tax havens, }}$, respectively, while Model 3 includes both of them. Table 2 shows that the effects of non-conventional outbound FDI on Japanese MNEs’ domestic employment levels heavily depend on the types of investment motivations of these non-conventional FDI projects as follows.

First, all coefficients of the motivational dummies for outbound FDI aiming to avoid trade barriers (M1) are negative and statistically significant at $1 \%$ across the three models, suggesting that non-conventional outbound FDI aiming to counter trade barriers is likely to reduce the MNEs' domestic employment levels. Outbound FDI to counter trade barriers is to arbitrage international political risks involved in trade disputes between home and host country governments, and MNEs would like to bypass the regulatory tariff and non-tariff trade barriers by shifting their domestic production facilities to their major exporting countries with strong protectionism. Such international reconfiguration of physical production activities generates a greater likelihood of protecting existing FSAs for the core businesses of MNEs in host countries, and MNEs commonly staff the new foreign production facilities established in host countries with local employees to support the core businesses 
therein, resulting in the reduction of domestic employment in the home countries where these MNEs are headquartered. The empirical evidence in Table 2 provides strong support for this argument in Hypothesis 1.

Second, all the coefficients of the motivational dummies for outbound FDI used as a financial hedge (M2) have the expected positive signs with 5\% statistical significance, confirming that nonconventional outbound FDI for financial hedging is likely to increase the domestic employment levels of Japanese MNEs. Outbound FDI for financial hedge does not add to the core businesses of MNEs in host countries, because it belongs to non-core functional activities of MNEs, and, as a result, it is not accompanied by establishing any physical production and/or service activities in their host countries targeting local customers. However, it is to proactively arbitrage potential financial risks and uncertainties from foreign exchange rate fluctuations and to secure access to capital resources in foreign countries, both of which require cross-national financial management centralized at the headquarters in the MNEs' home nations, resulting in the increase of domestic employment hired in the home countries of these MNEs. The evidence in Table 2 provides support for Hypothesis 2.

Third, all of the coefficients of the motivational dummies for outbound FDI seeking tax breaks in non-tax-haven countries $\left(M 3_{\text {Non-tax havens }}\right)$ are negative and statistically significant at $5 \%$. This indicates that non-conventional outbound FDI aimed to arbitrage national differences of tax liabilities provided by non-tax-haven countries are likely to reduce the home employment levels of Japanese MNEs, because MNEs can continue to protect existing FSAs for their core businesses in the host countries by relocating their core physical production/service facilities (and their source of hiring labor forces, too) to the foreign host countries to exploit the full tax incentive benefits from the host country governments. The evidence in Table 2 provides support to this argument in Hypothesis 3(a). However, all of the coefficients of the investment motivation for outbound FDI in tax-haven countries $\left(M 3_{\text {Tax havens }}\right)$ are statistically insignificant across all relevant models, suggesting that nonconventional FDI in tax havens to arbitrage international tax liabilities have no statistically significant impact on the domestic employment levels of Japanese MNEs. As aforementioned, outbound FDI in 
tax havens is for MNEs to set up foreign subsidiaries on paper without generating new FSAs to their core manufacturing and/or service businesses in host countries, and, accordingly, without hiring new employees in the MNEs' home country. Therefore, Hypothesis 3(b) is supported with the evidence in Table 2.

To guarantee the robustness of the empirical findings, two sets of robustness tests are conducted as reported in Table $3 .{ }^{8}$ First, we use $(t+1)$ lagged variable of the domestic employment levels in our 3SLS regressions to see whether incorporating alternative time lag between the outbound FDI motivations and the MNEs' domestic employment levels change our empirical findings. Second, we use the system generalized method of moments (GMM) on the parent MNE employment equation (1) as an alternative to the 3SLS empirical model to confirm that our findings are not sensitive to potential endogeneity or autocorrelation issues. ${ }^{9}$ All of the robustness checks in Table 3 show qualitatively similar results to our main findings reported in Table 2.

\section{Discussion and Conclusion}

This study empirically examines the effects of non-conventional forms of outbound FDI on Japanese MNEs' home-base employment levels. The theoretical foundations of our study are rooted in the literature on strategic ‘motivations' and international ‘activities' of MNEs who choose outbound FDI as their entry mode at a firm-level, and we use both dimensions of MNEs' international strategy as the key building blocks for explaining whether and how non-conventional outbound FDI may affect domestic employment levels of MNEs at home. We employ 3SLS regression techniques to address

\footnotetext{
${ }^{8}$ Following Hines and Rice (1994) and Desai et al. (2006), we have also divided our current tax haven countries into two groups, i.e., (1) Dot tax havens and (2) Big 7 tax havens, and conducted additional robustness tests using these sub-samples. The robustness test results did not change qualitatively our main findings and other robustness checks reported in Tables 2 and 3.

${ }^{9}$ The system GMM consists of the 'level' equation and the 'difference' equation, and uses lagged differences and lagged levels as instrumental variables (IVs) to estimate the level and difference equations, respectively. To guarantee the statistic validity of the selected IVs, (1) Hansen's J test and (2) the difference-in-Hansen test are conducted. In addition, AR(1) and AR(2) tests using the first-differenced residuals are conducted to check whether the original error terms are not serially correlated. If the original error terms in the level equation are not serially correlated, the AR(1) test results should be statistically significant whereas the AR(2) test results should be insignificant. The last three columns in Table 3 (Models 4 - 6) show that the system GMM estimators passed all of these specification tests.
} 
the endogeneity issue of foreign-subsidiary employment level in the determination of parent MNEs' domestic employment level.

We find that certain types of non-conventional outbound FDI can have a negative impact on domestic employment. This is especially true when the outbound FDI generates a greater likelihood of protecting existing FSAs for the core businesses of MNEs in foreign countries regardless of whether the MNEs aim to arbitrage international political risks or tax liabilities across national borders using non-conventional outbound FDI (e.g., FDI against trade barriers and FDI for tax incentive packages in non-tax-haven countries). We also find that other types of non-conventional outbound FDI are likely to increase the domestic employment levels of MNEs at home: those with arbitrage of international financial risks with new FSAs developed or accumulated from the MNEs’ non-core businesses (e.g., FDI for financial hedging). Finally, this study confirms that, when implementing outbound FDI to arbitrage international tax liabilities in tax haven countries without any core businesses relocated therein, its impact on the MNEs' home employment levels is insignificant.

Taken together, this study contributes to the current international business literature in terms of two aspects. First, this study theorizes whether and how non-conventional outbound FDI may affect domestic employment of MNEs at home from a combination of strategic 'motivations' and international ‘activities' of MNEs who choose outbound FDI as their entry mode into foreign countries. Specifically, the motivations of MNEs intended for conducting outbound FDI (i.e., 'Ownership/Internalization Advantages' versus ‘Responses to Location-specific Conditions') and the activities that MNEs actually implement in host countries (i.e., 'Core’ versus ‘Non-core’ business activities) put forward strong theoretical channels between the non-conventional outbound FDI and domestic employment of MNEs at a firm-level. Second, according to Cell IV of Figure 1 in Section 2, MNEs implement FDI in search for non-conventional types of country-specific advantages abroad, and such FDI implemented by MNEs could be accompanied by certain effects on the economy of home countries where the MNEs are headquartered. In the case of conventional FDI in Cell II, there have been a few studies that investigated such home-country employment effects of MNEs' outbound 
FDI and their FDI motivations. For example, using country-level data on FDI, trade, and employment, Agarwal $(1996,1997)$ showed a positive relationship between outbound FDI and home-country employment for natural resource-seeking and market-seeking motivations, but a negative relationship between these two for efficiency-seeking motivation; and Hijzen, Jean \& Mayer (2011) confirmed the positive home-country employment effects of market-seeking motivation in both manufacturing and service sectors. However, the operationalization of FDI motivations used in these studies was based on country-level characteristics of foreign markets and hence failed to capture the heterogeneity in firm-specific FDI motivations among MNEs invested in the same host countries. Although Hong, Lee \& Makino (2018) attempted to use firm-level data on MNEs' outbound FDI and their motivations of setting up overseas subsidiaries, the study was also confined to conventional forms of FDI only. Our current study addressed the knowledge gap in Cell IV of Figure 1 using Japanese MNEs, outbound FDI with their revealed motivations, and the Japanese parent MNEs' home employment levels in terms of non-conventional FDI. This study complemented the previous literature by showing that nonconventional outbound FDI to counter trade barriers or for tax incentive packages reduces MNEs' domestic employment levels, while outbound FDI for financial hedging or in tax havens has either a positive or insignificant effect on MNEs’ domestic employment levels.

These findings from our study also contribute to the body of policy-oriented discussions on the outcomes of non-conventional types of outbound FDI by empirically evaluating whether they are beneficial or detrimental or irrelevant to MNEs and their home country in terms of their impacts on home employment levels. First, the study shows that, regardless of arbitraging risks or liabilities across national borders, non-conventional outbound FDI may not be desirable for both MNEs and their home country in the long term. It is not desirable to MNEs, because MNEs could further strengthen their competitive advantages by shifting their resources and commitment used in this nonconventional outbound FDI toward conventional FDI types that could directly enhance their capability of conducting market-seeking or resource-seeking operations in foreign countries. It is not 
desirable for MNEs' home country, either, because it could negatively affect domestic employment of MNEs at home, as this study clearly finds.

Second, in light of the fact that most governments are concerned about boosting domestic employment, this study provides public policymakers with valuable insight. Many MNEs are prompted to engage in non-conventional outbound FDI projects as firm-level solutions to the international political discrepancies such as trade barriers and uneven domestic corporate tax rates across home and host countries of MNEs. However, our study shows that such FDI projects have a negative impact on domestic employment of MNEs. As such, governments' efforts to resolve trade barriers and to develop optimal domestic tax regimes end up being effective ways to keep the domestic employment levels within their jurisdictions.

Third, this study finds that outbound FDI for financial hedging has a positive effect on MNEs' domestic employment levels, whereas the impacts of outbound FDI in tax havens are insignificant. The implication from these asymmetric findings is that proper cross-national financial management in the form of FDI for financial hedging strengthens MNEs' business operations that create domestic employment opportunities, whereas MNEs' investments in tax havens do not. In other words, the opportunity cost of the latter type of investment in creating domestic employment is higher than that of the former type. Any government policy proposals providing incentives for firms that increase domestic employment must evaluate carefully the country of destination for the outflows of MNEs' direct investment to guarantee their policy effects.

This study has several limitations, which future studies could address. First, although conventional and non-conventional forms of outbound FDI are conceptually distinguishable using the ‘motivation-activity’ of MNEs, non-conventional outbound FDI could be accompanied by conventional outbound FDI in host countries, generating confounding effects between these two. For example, when MNEs transfer core manufacturing activities into foreign markets either to counter trade barriers or for tax incentive packages therein, they would also like to utilize country-specific resources available in the host countries as classified by Dunning (1998). In this case, such non- 
conventional outbound FDI plays concurrently a complementary role to the conventional outbound FDI, blurring the line between the two. Second, our study does not cover all possible cases of nonconventional forms of outbound FDI that could be conducted by MNEs, and we acknowledge that MNEs are expected to engage in more diverse forms of non-conventional outbound FDI in the future to survive the stronger competition and the transborder inefficiency in the global economy. Third, owing to a lack of information on micro-level employment characteristics, this study examined only the effect of non-conventional types of outbound FDI for the aggregate counts of domestic employment. Considering diverse features of employment in terms of employment levels, worker types, and part-time versus full-time employment status, future studies could empirically distinguish employment characteristics when data at further disaggregate levels become available. It is likely that an important effect of non-conventional FDI is to change the composition of employment in the home base as well as the absolute level of domestic employment. Fourth, we acknowledge that the domestic employment hired by MNEs at home may not be the only way to evaluate the impact of nonconventional outbound FDI on the MNEs' domestic economy. Scholars are encouraged to develop alternative measures to represent the welfare effects of MNEs' outbound FDI on their home economy, e.g., labor productivity of parent MNEs at home, when such data become readily available for scholarly use. Fifth, whether the use of Japan as a context for this research is relevant or not is an issue to be addressed in future studies. One can argue that we need to confirm the generalizability of the finding in other national contexts. To do so, we need to conduct the same analyses using a sample of non-Japanese MNEs and confirm whether the same results are obtained. Others may argue that the generalizability of the findings is unnecessary or even impossible, because FDI decisions (i.e., motivations and activities) cannot be analyzed in isolation of country contexts that are unique across countries. In either case, since our sample comes from a single country context, i.e., Japan, we cannot confirm whether the results are generalizable across countries or unique to a specific country context. We can therefore say at best that our analyses simply provide an 'abductive inference' (or inference to the best explanation) regarding the effect of non-conventional outbound FDI on domestic employment 
of MNEs at home. Lastly, we could not control for all aspects of Japanese parent MNEs in our regression analyses which may affect their employment levels hired at home. Future studies are advised to consider including e.g. the growth of parent MNEs and/or the labor intensity of industries where they currently operate as additional controls if they are readily available. There is much to be done on this important and increasing phenomenon of non-conventional forms of outbound FDI employed by MNEs, and we hope that other IB scholars will join us in this important line of research. 


\section{References}

Agarwal, J.P. (1996). Does foreign direct investment contribute to unemployment in home countries? An empirical survey. Kiel Working Paper No.765, Kiel Institute for the World Economy.

Agarwal, J.P. (1997). Effect of foreign direct investment on employment in home countries. Transnational Corporations, 6, 1-28.

Aitken, B. J., \& Harrison, A. E. (1999). Do domestic firms benefit from foreign direct investment? Evidence from Venezuela. American Economic Review, 89(3), 605-618

Almeida, R. (2007). The labor market effects of foreign owned firms. Journal of International Economics, 72(1), 75-96.

Altomonte, C., \& Pennings, E. (2009). Domestic plant productivity and incremental spillovers from foreign direct investment. Journal of International Business Studies, 40(7), 1131-1148.

Altzinger, W., \& Bellak, C. (1999). Direct versus Indirect FDI: Impact on Domestic Exports and Employment. Working Paper Series: Sustainability and Competitiveness $\mathrm{N}^{\circ}$ 9. Vienna University of Economics and Business Administration, Vienna, November.

Arslan, A., \& Dikova D. (2015). Influences of Institutional Distance and MNEs’ Host Country Experience on the Ownership Strategy in Cross-Border M\&As in Emerging Economies. Journal of Transnational Management, 20(4), 231-256.

Ayyagari, M., \& Kosová, R. (2010). Does FDI facilitate domestic entry? Evidence from the Czech Republic. Review of International Economics, 18(1), 14-29.

Barbosa, N., \& Eiriz, V. (2009). The role of inward foreign direct investment on entrepreneurship. International Entrepreneurship and Management Journal, 5(3), 319-339.

Beamish, P.W., Delios, A., \& Makino, S. (2001). Japanese Subsidiaries in the New Global Economy. Cheltenham, UK: Edward Elgar.

Becker, S.O., Ekholm, K., Jäckle, R., \& Muendler, M.A. (2005). Location choice and employment decisions: a comparison of German and Swedish multinationals. Review of World Economics, 141(4), 693-731.

Becker, S.O., \& Muendler, M.A. (2008). The effect of FDI on job security. The B.E. Journal of Economic Analysis \& Policy, 8(1), Article 8.

Berry, H. (2015). Knowledge Inheritance in Global Industries: The Impact of Parent Firm Knowledge on the Performance of Foreign Subsidiaries. Academy of Management Journal, 58(5), 14381458.

Beuglesdijk, S., Hennart, J.-F., Slangen, A., \& Smeets, R. (2010). Why and how FDI stocks are a biased measure of MNE affiliate activity. Journal of International Business Studies, 41(6), 1444-1459.

Blonigen, B.A., \& Feenstra, R.C. (1997). Protectionist Threats and Foreign Direct Investment. In R. Feenstra (Eds.), Effects of U.S. Trade Protection and Promotion Policies (pp.54-80). Chicago: University of Chicago Press.

Borrmann, C., Jungnickel, R., \& Keller, D. (2005). What Gravity Models Can Tell Us About the Position of German FDI in Central and Eastern Europe. HWWA Discussion Paper No. 328. Hamburg Institute of International Economics.

Buchanan, B.G., Le, Q.V., \& Rishi, M., (2012). Foreign direct investment and institutional quality: Some empirical evidence. International Review of Financial Analysis, 21, 81-89.

Buckley, P., \& Casson, M. (1976). The Future of the Multinational Enterprise. London: Holmes and Meier.

Buckley, P.J., Clegg, J., Forsans, N., \& Reilly, K.T. (2003). Evolution of FDI in the United States in the context of trade liberalization and regionalization. Journal of Business Research, 56, 853857.

Buckley, P. J., Clegg, J., \& Wang, C. (2006). Inward FDI and host country productivity: Evidence from China's electronics industry. Transnational Corporations, 15(1), 13-37. 
Buckley, P. J., Clegg, J., \& Wang, C. (2007). Is the relationship between inward FDI and spillover effects linear? An empirical examination of the case of China. Journal of International Business Studies, 38(3), 447-459.

Burke, A., Görg, H., \& Hanley, A. (2008). The impact of foreign direct investment on new firm survival in the UK: Evidence for static versus dynamic industries. Small Business Economics, 31(4), 395-407.

Chan, C.M., Isobe, T., \& Makino, S. (2008). Which country matters? Institutional development and foreign affiliate performance. Strategic Management Journal, 29(11), 1179-1205.

Chari, M., \& Acikgoz, S. (2016). What drives emerging economy firm acquisitions in tax havens? Journal of Business Research, 69, 664-671.

Chen, T.-J., \& Ku, Y.-H. (2005). The effects of overseas investment on domestic employment. In T. Ito and A.K. Rose (Eds.), International Trade in East Asia, NBER-East Asia Seminar on Economics. vol. 14 (pp.109-127). Chicago: University of Chicago Press.

Clark, W.S. (2008). Assessing the FDI Response to Tax Reform and Tax-Planning. Available at SSRN: http://www.oecd.org/ctp/tax-policy/39975841.pdf.

Cuyvers, L., \& Soeng, R. (2011). The effects of Belgian outward direct investment in European highwage and low-wage countries on employment in Belgium. International Journal of Manpower, 32(3), 300-312.

De Backer, K., \& Sleuwaegen, L. (2003). Does foreign direct investment crowd out domestic entrepreneurship? Review of Industrial Organization, 22(1), 67-84.

Debaere, P., Lee, H., \& Lee, J. (2010). It matters where you go: outward foreign direct investment and multinational employment growth at home. Journal of Developmental Economics, 91(2), 301-309.

Dekle, R. (2002). Industrial concentration and regional growth: Evidence from the prefectures. Review of Economics and Statistics, 84(2), 310-315.

Delios, A., \& Beamish, P.W. (2001). Survival and profitability: The roles of experience and intangible assets in foreign subsidiary performance. Academy of Management Journal, 44(5), 1028-1038.

Deng, P. (2004). Outward investment by Chinese MNEs: Motivations and implications. Business Horizons, 47, 8-16.

Desai, M.A., Foley, C.F., \& Hines Jr., J.R. (2006). The demand for tax havens. Journal of Public Economics, 90, 513-531.

Desai, M.A., Foley, C.F., \& Hines Jr., J.R. (2009). Domestic effects of the foreign activities of US multinationals. American Economic Journal: Economic Policy, 1(1), 181-203.

Dharmapala, D. (2008). What Problems and Opportunities are Created by Ta x Havens? Oxford Review of Economic Policy, 24, 661-679.

Dinga, M., \& Mnich, D. (2010). The impact of territorially concentrated FDI on local labor markets: Evidence from the Czech Republic. Labour Economics, 17(2), 354-367.

Driffield, N., Pereira, V., \& Temouri, Y. (2017). Does offshore outsourcing impact home employment? Evidence from service multinationals. Journal of Business Research, https://doi.org/10.1016/j.jbusres.2017.09.051.

Dunning, J.H. (1998). Location and the multinational enterprise: A neglected factor? Journal of International Business Studies, 29(1), 45-66.

Dunning, J.H., van Hoesel, R., \& Narula, R. (1996). Explaining the 'new' wave of outward FDI from developing countries: The case of Taiwan and Korea. Research Memoranda 009, Maastricht Economic Research Institute on Innovation and Technology.

Fang, Y., Jiang, G.-L.F., Makino, S., \& Beamish, P.W. (2010). Multinational firm knowledge, use of expatriates, and foreign subsidiary performance. Journal of Management Studies, 47(1), 2754.

Federico, S., \& Minerva, G. (2008). Outward FDI and local employment growth In Italy. Review of World Economics, 144(2), 295-324. 
Fenton-O’Creevy, M., Gooderham, P., \& Nordhaug, O. (2008). HRM In US subsidiaries in Europe and Australia: centralization or autonomy? Journal of International Business Studies, 39(1), 151-166.

Goldberg, L. (2004). Financial-Sector FDI and Host Countries: New and Old Lessons. NBER Working Paper, No.10441.

Gomez, C., \& Sanchez, J. (2005). Human Resource Control in MNCs: A Study of the Factors Influencing the Use of Formal and Informal Control Mechanisms. International Journal of Human Resource Management, 16(10), 1847-1861.

Görg, H., \& Greenway, D. (2004). Much ado about nothing? Do domestic firms really benefit from foreign direct investment? World Bank Research Observer, 19(2), 171-197.

Görg, H., \& Strobl, E. (2002). Multinational companies and indigenous development: An empirical analysis. European Economic Review, 46(7), 1305-1322.

Greene, W.H. (2008). Econometric Analysis. Upper Saddle River, NJ: Prentice-Hall.

Haddad, M., \& Harrison, A.E. (1993). Are there positive spillovers from direct foreign investment? Journal of Development Economics, 42(1), 51-74.

Harrison, A.E., \& McMillan, M.S. (2007). U.S. multinational activity abroad and U.S. jobs: substitutes or complements? Industrial Relations, 46(2), 347-365.

Haskel, J.E., Pereira, S.C., \& Slaughter, M.J. (2007). Does inward foreign direct investment boost the productivity of domestic firms? The Review of Economics and Statistics, 89(3), 482-496.

Hennart, J.F. (1982). A Theory of Multinational Enterprise. Ann Arbor, MI: University of Michigan Press.

Hennart, J.F. (2009). The Theories of The Multinational Enterprise. In A.M. Rugman (Eds.), The Oxford Handbook of International Business, 2nd Edition (pp.125-145). Oxford: Oxford University Press.

Hijzen, A., Inui, T., \& Todo, Y. (2007). The effects of multinational production on domestic performance: evidence from Japanese firms. RIETI Discussion Paper Series, No. 07-E-006. Research Institute of Economy, Trade and Industry, Tokyo.

Hijzen, A., Jean, S., \& Mayer, T. (2011). The effects at home of initiating production abroad: Evidence from matched French firms. Review of World Economics, 147(3), 457-483.

Hijzen, A., Martins, P.S., Schank, T., \& Upward, R. (2013). Foreign-owned firms around the world: A comparative analysis of wages and employment at the micro-level. European Economic Review, 60(2), 170-188.

Hines, J., \& Rice, E.M. (1994). Fiscal Paradise: Foreign Tax Havens and American Business. Quarterly Journal of Economics, 109(1), 149-182.

Hong, E., Lee, I.H., \& Makino, S. (2018). Outbound Foreign Direct Investment (FDI) Motivation and Domestic Employment by Multinational Enterprises (MNEs). Journal of International Management, https://doi.org/10.1016/j.intman.2018.11.003.

Hymer, S.H. (1976). The International Operations of National Firms: A Study of Direct Foreign Investment. Cambridge, MA: MIT Press.

Jones, C., \& Temouri, Y. (2016). The determinants of tax haven FDI. Journal of World Business, 51, 237-250.

Jude, C., \& Silaghi, M.I.P. (2015). Employment effects of foreign direct investment: New evidence from Central and Eastern European countries. International Economics, 145, 32-49.

Kokko, A. (2002). FDI and the structure of home country production. In B. Bora (eds.), Research Issues in Foreign Direct Investment (pp.152-167). London: Routledge.

Kokko, A. (2006). The home country effects of FDI in developed economies. EIJS Working Paper No. 225, European Institute of Japanese Studies, Stockholm.

Konigs, J., \& Murphy, A. (2006). Do multinational enterprises relocate employment to low-wage regions? Evidence from European multinationals. Review of World Economics, 142, 267-286. 
Kottaridi, C., Giakoulas, D., \& Manolopoulos, D. (2019). Escapism FDI from developed economies: The role of regulatory context and corporate taxation. International Business Review, 28, 3647.

Kuemmerle, W. (1997). Building effective capabilities abroad. Harvard Business Review, 75, 61-70.

Lee, I.H., Hong, E., \& Sun, L. (2014). Inward foreign direct investment and domestic entrepreneurship: A regional analysis of new firm creation in Korea. Regional Studies, 48(5), 910-922.

Lippman, S.A., \& Rumelt, R.P. (1982). Uncertain imitability: An analysis of interfirm differences in efficiency under competition. Bell Journal of Economics, 13(2), 418-438.

Liu, H., \& Lu, J. (2009). The home-employment effect of foreign direct investment: in the case of China. Tianjin, China.

Mariotti, S., Mutinelli, M., \& Piscitello, L. (2003). Home country employment and foreign direct investment: evidence from the Italian case. Cambridge Journal of Economics, 27, 419-431.

Martin, P., \& Rogers, C. (2000). Long-term growth and short-term economic instability. European Economic Review, 44(2), 359-381.

Masso, J., Varblane, U., \& Vahter, P. (2008). The effect of outward investment on home country employment in a low cost transition economy. Eastern European Economics, 46, 25-59.

Mitra, D., \& Ranjan, P. (2010). Offshoring and unemployment: The role of search frictions labor mobility. Journal of International Economics, 81(2), 219-229.

Molnar, M., Pain, N., \& Taglioni, D. (2007). The internationalisation of production, international outsourcing and employment in the OECD. OECD Economics Department Working Papers 561, OECD.

Molnar, M., Pain, N., \& Taglioni, D. (2008). Globalisation and Employment in the OECD. OECD Economic Studies No. 44, OECD, Paris.

Moosa, I. A., \& Cardak, B. A. (2006). The determinants of foreign direct investment: An extreme bounds analysis. Journal of Multinational Financial Management, 16(2), 199-211.

Motohashi, K., \& Yuan, Y. (2010). Productivity impact of technology spillover from multinationals to local firms: Comparing China's automobile and electronics industries. Research Policy, 39(6), 790-798.

Morck, R., Yeung, B., \& Zhao, M. (2008). Perspectives on China's outward foreign direct investment. Journal of International Business Studies, 39, 337-350

OECD. (2002). Foreign direct investment for development. Organization for Economic Co-operation and Development.

Pajunen, K. (2008). Institutions and inflows of foreign direct investment: A fuzzy-set analysis. Journal of International Business Studies, 39(4), 652-669.

Pantzalis, C., Simkins, B.J., \& Laux, P. (2001). Operational Hedges and the Foreign Exchange Exposure of US Multinational Corporations. Journal of International Business Studies, 32(4), 793-812.

Peluffo, A. (2015). Foreign direct investment, productivity, demand for skilled labour and wage inequality: An analysis of Uruguay. World Economy, 38(6), 962-983.

Rogerson, P.A. (2001). Statistical methods for geography. London: Sage.

Rugman, A.M. (1981). Inside the multinationals: The economics of internal markets. New York: Columbia University Press.

Rugman, A.M. (2005). The Regional Multinationals. Cambridge: Cambridge University Press.

Rugman, A.M. (2010). Reconciling Internalization Theory and the Eclectic Paradigm. Multinational Business Review, 18(2), 1-12.

Rugman, A.M., \& Verbeke, A. (2004). Perspective on regional and global strategies of multinational enterprises. Journal of International Business Studies, 35(1), 3-18.

Rugman, A.M., Verbeke, A., \& Nguyen, Q.T.K. (2011). Fifty years of international business theory and beyond. Management International Review, 51(6), 755-786. 
Rumelt, R.P. (1984). Towards a strategic theory of the firm. In R.B. Lamb (Eds.), Competitive Strategic Management (pp.556-570). Englewood Cliffs, NJ: Prentice-Hall.

Slemrod, J., \& Wilson, J.D. (2009). Tax Competition with Parasitic Tax Havens. Journal of Public Economics, 93(11-12), 1261-1270.

South China Morning Post. (2019). US trade war has cost China 'almost 2 million industrial jobs', investment bank CICC says. Published online: https://www.scmp.com/economy/chinaeconomy/article/3019916/us-trade-war-has-cost-china-almost-2-million-industrial-jobs on July 24th.

Stoian, C., \& Mohr, A. (2016). Outward foreign direct investment from emerging economies: Escaping home country regulative voids. International Business Review, 25, 1125-1136.

Suárez Serrato, J.C. (2018). Unintended consequences of eliminating tax havens. NBER Working Paper, No. 24850. (https://www.nber.org/papers/w24850)

Sun, L., Lee, I.H., \& Hong, E. (2017). Does foreign direct investment stimulate new firm creation? In search of spillovers through industrial and geographical linkages. Small Business Economics, 48, 613-631.

Sune, K., Nannan, L., Fredrik, S., \& Ping, H. (2009). Foreign firms and Chinese employment. World Economy, 32(1), 178-201.

Tang, J. \& Altshuler, R. (2015). The Spillover effects of outward foreign direct investment on home countries: Evidence from the United States. Retrieved from http://www.sbs.ox.ac.uk/sites/default/files/Business Taxation/Docs/Publications/Working Pa pers/Series 15/WP1503.pdf

Uddin, M., \& Boateng, A. (2011). Explaining the trends in the UK cross-border mergers \& acquisitions: An analysis of macro-economic factors. International Business Review, 20(5), 547-556.

UNCTAD Statistics Data Center. Available at https://unctadstat.unctad.org.

Urata, S. (1993). Japanese foreign direct investment and its effects on foreign trade in Asia. In T. Ito and A.O. Krueger (Eds.), Trade and Protectionism (pp.273-304). Chicago: University of Chicago Press.

Vahter, P., \& Masso, J. (2007). Home versus host country effects of FDI: Searching for new evidence of productivity spillovers. Applied Economics Quarterly, 53, 165-196.

Verbeke, A., \& Kano, L. (2016). An internalization theory perspective on the global and regional strategies of multinational enterprises. Journal of World Business, 51(1), 83-92.

Waldkirch, A., \& Nunnenkamp, P. (2009). Employment effects of FDI in Mexico's non-maquiladora manufacturing. Journal of Development Studies, 45(7), 1165-1183.

Wang, X., Xu, L. C., \& Zhu, T. (2012). Foreign direct investment under a weak rule of law. Economics of Transition, 20(3), 401-424. 
Figure 1: Literature on FDI and its Effects

\begin{tabular}{|c|c|c|c|}
\hline & & \multicolumn{2}{|c|}{ Effects of FDI } \\
\hline & & Host-Country Effects & Home-Country Effects \\
\hline \multirow{30}{*}{$\begin{array}{l}\text { Types of } \\
\text { FDI }\end{array}$} & \multirow{24}{*}{$\begin{array}{c}\text { Conventional } \\
\text { FDI }\end{array}$} & \multirow{8}{*}{$\begin{array}{l}\underline{\text { Cell I }} \\
\text { Haddad \& Harrison (1993) } \\
\text { Aitken \& Harrison (1999) } \\
\text { Görg \& Greenway (2004) } \\
\text { Buckley, Clegg \& Wang (2006, 2007) } \\
\text { Haskel, Pereira \& Slaughter (2007) } \\
\text { Vahter \& Masso (2007) } \\
\text { Altomonte \& Pennings (2009) } \\
\text { Motohashi \& Yuan (2010) }\end{array}$} & Cell II \\
\hline & & & Kokko (2002) \\
\hline & & & Vahter \& Masso (2007) \\
\hline & & & Tang \& Altshuler (2015) \\
\hline & & & Becker et al (2005) \\
\hline & & & Kokko (2006) \\
\hline & & & Agarwal (1996, 1997) \\
\hline & & & Hijzen, Inui \& Todo (2007) \\
\hline & & \multirow{5}{*}{$\begin{array}{l}\text { Görg \& Strobl (2002) } \\
\text { De Backer \& Sleuwaegen (2003) } \\
\text { Burke, Görg \& Hanley (2008) } \\
\text { Barbosa \& Eiriz (2009) } \\
\text { Ayyagari and Kosová (2010) }\end{array}$} & Becker \& Muendler (2008) \\
\hline & & & Federico \& Minerva (2008) \\
\hline & & & Masso, Varblane \& Vahter (2008) \\
\hline & & & Desal, Foley \& Hines Jr. (2009) \\
\hline & & & Cuyvers \& Soeng (2011) \\
\hline & & \multirow{11}{*}{$\begin{array}{l}\text { Lee, Hong \& Sun (2014) } \\
\text { Sun, Lee \& Hong (2017) } \\
\text { Almeida (2007) } \\
\text { Dinga \& Mnich (2010) } \\
\text { Peluffo (2015) } \\
\text { Sune et al. (2009) } \\
\text { Waldkirch \& Nunnenkamp (2009) } \\
\text { Hijzen et al. (2013) } \\
\text { Jude \& Silaghi (2015) }\end{array}$} & Altzinger \& Bellak (1999) \\
\hline & & & Mariotti, Mutinelli \& Piscitello (2003) \\
\hline & & & Chen \& Ku (2005) \\
\hline & & & Konigs \& Murphy (2006) \\
\hline & & & Harrison \& McMillan (2007) \\
\hline & & & Molnar, Pain \& Taglioni $(2007,2008)$ \\
\hline & & & Debaere, Lee \& Lee (2010) \\
\hline & & & Mitra \& Ranjan (2010) \\
\hline & & & Hijzen, Jean \& Mayer (2011) \\
\hline & & & Driffield, Pereira \& Temouri (2017) \\
\hline & & & Hong, Lee \& Makino (2018) \\
\hline & \multirow{6}{*}{$\begin{array}{c}\text { Non- } \\
\text { conventional } \\
\text { FDI }\end{array}$} & Cell III* & Cell IV \\
\hline & & Jones \& Temouri (2016) & \\
\hline & & Chari \& Acikgoz (2016) & \\
\hline & & Stoian \& Mohr (2016) & \\
\hline & & Kottaridi, Giakoulas \& Manolopoulos & \\
\hline & & (2019) & \\
\hline
\end{tabular}

* These studies focus on uncovering the host country-specific determinants of non-conventional FDI, not its consequences or outcomes on the host countries. 
Figure 2: Conventional versus Non-conventional Outbound FDI of MNEs

(a) Conventional Outbound FDI

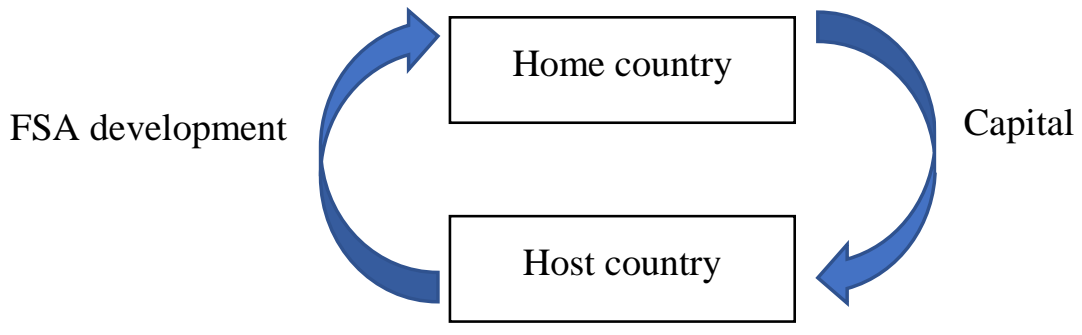

Activities in core business

(b) Non-conventional Outbound FDI

(i) FDI to counter trade barriers or FDI for tax incentive packages in non-tax havens

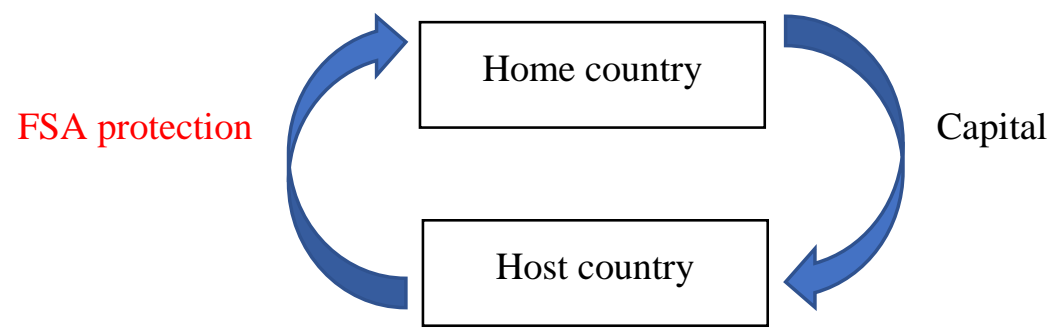

Activities in core business

(ii) FDI for financial hedge

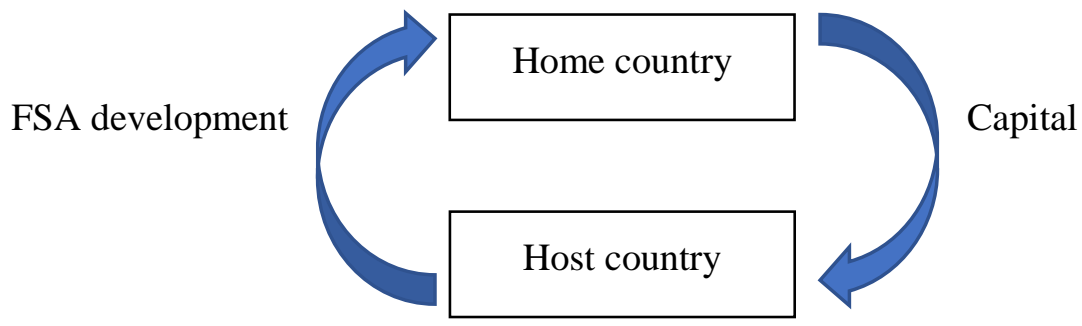

Activities in non-core business

(iii) FDI for tax breaks in tax havens

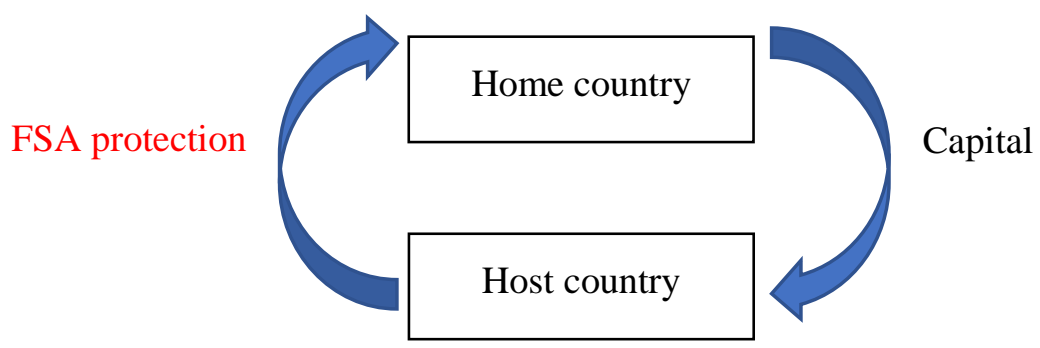

Activities in non-core business 
Figure 3: Activities and Motivations of MNEs for Outbound FDI

\begin{tabular}{|c|c|c|c|}
\hline \multicolumn{2}{|c|}{} & \multicolumn{2}{|c|}{ Motivations for Outbound FDI } \\
\cline { 3 - 4 } \multicolumn{2}{|c|}{} & $\begin{array}{c}\text { Ownership/Internalization } \\
\text { Advantages }\end{array}$ & $\begin{array}{c}\text { Responses to (Legal and Regulatory) } \\
\text { Location-specific Conditions }\end{array}$ \\
\hline $\begin{array}{c}\text { Activities } \\
\text { in Host } \\
\text { Countries }\end{array}$ & $\begin{array}{c}\text { In Core } \\
\text { Business }\end{array}$ & Conventional FDI & $\begin{array}{c}\text { H1: FDI to counter trade barriers } \\
\text { H3(a): FDI for tax incentive packages } \\
\text { in non-tax havens }\end{array}$ \\
\cline { 2 - 4 } & $\begin{array}{c}\text { In Non-core } \\
\text { Business }\end{array}$ & H2: FDI for financial hedge & H3(b): FDI for tax breaks in tax havens \\
\hline
\end{tabular}


Table1: Descriptive Statistics and Correlation Matrix

\begin{tabular}{|c|c|c|c|c|c|c|c|c|c|c|c|c|c|c|c|}
\hline & Mean & Std. Dev & 1 & 2 & 3 & 4 & 5 & 6 & 7 & 8 & 9 & 10 & 11 & 12 & 13 \\
\hline 1 & 8.479 & 1.531 & 1.000 & & & & & & & & & & & & \\
\hline 2 & 3.954 & 1.742 & $0.317 * * *$ & 1.000 & & & & & & & & & & & \\
\hline 3 & 27.548 & 1.653 & $-0.088 * * *$ & $-0.062 * * *$ & 1.000 & & & & & & & & & & \\
\hline 4 & 8.528 & 6.483 & $0.019 * * *$ & $-0.473^{* * *}$ & $0.101^{* * *}$ & 1.000 & & & & & & & & & \\
\hline 5 & 4.605 & 0.521 & $0.018^{* *}$ & -0.003 & $-0.075 * * *$ & -0.011 & 1.000 & & & & & & & & \\
\hline 6 & 30.226 & 31.499 & $-0.015^{*}$ & $-0.184 * * *$ & $0.602 * * *$ & $0.225 * * *$ & 0.0002 & 1.000 & & & & & & & \\
\hline 7 & 0.839 & 0.858 & $-0.032 * * *$ & $-0.343 * * *$ & $0.162^{* * *}$ & $0.335^{* * *}$ & $0.017 * *$ & $0.603^{* * *}$ & 1.000 & & & & & & \\
\hline 8 & 0.571 & 0.783 & $0.477 * * *$ & $0.175^{* * *}$ & $0.247 * * *$ & $-0.058 * * *$ & $-0.012^{*}$ & $-0.021 * * *$ & $-0.186 * * *$ & 1.000 & & & & & \\
\hline 9 & 0.235 & 0.034 & $-0.033 * * *$ & $-0.028 * * *$ & $0.099 * * *$ & $0.061 * * *$ & $0.066 * * *$ & $0.074 * * *$ & $0.066 * * *$ & $-0.040 * * *$ & 1.000 & & & & \\
\hline 10 & 9.378 & 2.001 & $0.388^{* * *}$ & $0.525^{* * *}$ & $0.059 * * *$ & $-0.083^{* * *}$ & $-0.015^{*}$ & $0.153^{* * *}$ & $0.196 * * *$ & $0.142 * * *$ & $0.026^{* * *}$ & 1.000 & & & \\
\hline 11 & 0.020 & 0.140 & $-0.012^{*}$ & $0.080^{* * *}$ & $0.077 * * *$ & $-0.088 * * *$ & 0.001 & $0.100 * * *$ & $0.081^{* * *}$ & $-0.028 * * *$ & $-0.021 * * *$ & $0.082^{* * *}$ & 1.000 & & \\
\hline 12 & 0.014 & 0.118 & $0.018^{* *}$ & $-0.118 * * *$ & $-0.023 * * *$ & $0.014^{*}$ & $0.017 * *$ & $0.042 * * *$ & $0.077 * * *$ & -0.001 & $-0.026 * * *$ & $-0.034 * * *$ & $0.024 * * *$ & 1.000 & \\
\hline 13 & 0.055 & 0.228 & $0.040^{* * *}$ & $0.200^{* * *}$ & $-0.094 * * *$ & $-0.174 * * *$ & $0.015^{* *}$ & $-0.117 * * *$ & $-0.141^{* * *}$ & 0.001 & $-0.031^{* * *}$ & $0.061^{* * *}$ & $0.013^{*}$ & $-0.029 * * *$ & 1.000 \\
\hline 14 & 0.007 & 0.089 & $0.025 * * *$ & $0.033^{* * *}$ & $-0.105^{* * *}$ & $-0.044 * * *$ & 0.009 & $-0.053^{* * *}$ & $0.069 * * *$ & 0.002 & -0.003 & $0.049 * * *$ & $0.069 * * *$ & 0.0000 & $-0.022 * * *$ \\
\hline
\end{tabular}

1. Japanese parent MNE employment (ln); 2. Overseas subsidiary employment (ln); 3. Host country GDP (ln); 4. Ratio of Japanese GDP by industry (\%); 5. Unemployment rate in Japan (\%); 6. Distance between Japan and host countries (ln); 7. Rule of law; 8. Parent MNE local networks (ln); 9. Parent MNE R\&D ratio (\%); 10. Overseas subsidiary revenue (ln); 11. M1. Trade barriers; 12. M2. Financing, currency hedging;

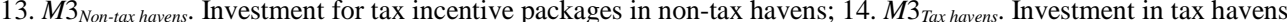


Table 2: 3SLS Regression Results (DV: Parent MNE employment)

\begin{tabular}{|c|c|c|c|}
\hline & Model 1 & Model 2 & Model 3 \\
\hline \multicolumn{4}{|l|}{ Non-conventional FDI motivations } \\
\hline M1. FDI to counter trade barriers & $-0.189 * * *[0.063]$ & $-0.186 * * *[0.063]$ & $-0.187 * * *[0.063]$ \\
\hline M2. FDI for financing, currency hedging & $0.167 * *[0.081]$ & $0.170^{* *}[0.081]$ & $0.167 * *[0.081]$ \\
\hline M3 $3_{\text {Non-tax havens. FDI for tax breaks in non-tax havens }}$ & $-0.093 * *[0.040]$ & & $-0.094 * *[0.040]$ \\
\hline M3 Tax havens. FDI for tax breaks in tax havens & & $-0.032[0.099]$ & $-0.045[0.100]$ \\
\hline \multicolumn{4}{|l|}{ Control variables } \\
\hline Overseas subsidiary employment (ln) & $0.518 * * *[0.010]$ & $0.517 * * *[0.010]$ & $0.518^{* * *}[0.010]$ \\
\hline Host country GDP (ln) & $-0.228 * * *[0.010]$ & $-0.228 * * *[0.010]$ & $-0.228 * * *[0.010]$ \\
\hline Ratio of Japanese GDP by industry (\%) & $0.036 * *[0.015]$ & $0.035^{* *}[0.015]$ & $0.036 * *[0.015]$ \\
\hline Unemployment rate in Japan (\%) & $2.381 * * *[0.086]$ & $2.387 * * *[0.086]$ & $2.380 * * *[0.086]$ \\
\hline Distance between Japan and host countries (ln) & $0.0004[0.001]$ & $0.0003[0.001]$ & $0.0004[0.001]$ \\
\hline Host country rule of law & $0.161 * * *[0.017]$ & $0.163 * * *[0.017]$ & $0.162^{* * *}[0.017]$ \\
\hline Parent MNE local networks (ln) & $0.859 * * *[0.013]$ & $0.859 * * *[0.013]$ & $0.859 * * *[0.013]$ \\
\hline Parent MNE R\&D ratio (\%) & $-0.029[0.266]$ & $-0.022[0.266]$ & $-0.028[0.266]$ \\
\hline Conventional FDI motivation dummies & Yes & Yes & Yes \\
\hline Industry fixed effects & Yes & Yes & Yes \\
\hline Regional fixed effects & Yes & Yes & Yes \\
\hline Yearly fixed effects & Yes & Yes & Yes \\
\hline Number of Observations & 17,788 & 17,788 & 17,788 \\
\hline $\mathrm{R}^{2}$ & 0.4436 & 0.4439 & 0.4436 \\
\hline$\chi^{2}$ & $997,061.72 * * *$ & $997,506.50 * * *$ & $997,000.08 * * *$ \\
\hline
\end{tabular}

Notes. Standard errors in brackets; ${ }^{* * *} p<0.01{ }^{* *} p<0.05$, ${ }^{*} p<0.1$, two-tailed tests. 
Table 3: Robustness Test Results (DV: Parent MNE employment)

\begin{tabular}{|c|c|c|c|c|c|c|}
\hline & \multicolumn{3}{|c|}{ Parent MNE Employment at $(t+1)$ : 3SLS Regression } & \multicolumn{3}{|c|}{ System GMM } \\
\hline & Model 1 & Model 2 & Model 3 & Model 4 & Model 5 & Model 6 \\
\hline \multicolumn{7}{|l|}{ Non-conventional FDI motivations } \\
\hline M1. FDI to counter trade barriers & $-0.103 * *[0.042]$ & $-0.201 * * *[0.066]$ & $-0.202 * * *[0.066]$ & $-17.950 * *[7.449]$ & $-20.394 * * *[7.532]$ & $-17.640 * *[7.681]$ \\
\hline M2. FDI for financing, currency hedging & $0.161 *[0.084]$ & $0.164 * *[0.083]$ & $0.161 *[0.084]$ & $1.662 *[0.994]$ & $1.858 *[1.054]$ & $1.727 *[1.029]$ \\
\hline M3Non-tax havens. FDI for tax breaks in non-tax havens & $-0.204 * * *[0.066]$ & & $-0.104 * *[0.042]$ & $-0.639 * *[0.255]$ & & $-0.644 * *[0.265]$ \\
\hline M3 Tax havens. FDI for tax breaks in tax havens & & $-0.023[0.104]$ & $-0.037[0.104]$ & & $1.561[1.086]$ & $1.262[1.036]$ \\
\hline \multicolumn{7}{|l|}{ Control variables } \\
\hline Overseas subsidiary employment (ln) & $0.519 * * *[0.011]$ & $0.518 * * *[0.011]$ & $0.519 * * *[0.011]$ & $0.409 * * *[0.046]$ & $0.396 * * *[0.050]$ & $0.387 * * *[0.050]$ \\
\hline Host country GDP (ln) & $-0.218 * * *[0.011]$ & $-0.218 * * *[0.011]$ & $-0.218 * * *[0.011]$ & $-0.192 *[0.101]$ & $-0.198 *[0.102]$ & $-0.186 *[0.010]$ \\
\hline Ratio of Japanese GDP by industry (\%) & $0.039 * *[0.016]$ & $0.038 * *[0.016]$ & $0.039 * *[0.016]$ & $-0.043[0.051]$ & $-0.044[0.050]$ & $-0.040[0.050]$ \\
\hline Unemployment rate in Japan (\%) & $2.618 * * *[0.087]$ & $2.621 * * *[0.087]$ & $2.618 * * *[0.087]$ & $-1.842[1.542]$ & $1.266[2.584]$ & $1.394[2.607]$ \\
\hline Distance between Japan and host countries (ln) & $0.0001[0.001]$ & $-0.0001[0.001]$ & $0.0001[0.001]$ & $0.070 *[0.042]$ & $0.072 *[0.043]$ & $0.074 *[0.043]$ \\
\hline Host country rule of law & $0.168 * * *[0.018]$ & $0.170 * * *[0.018]$ & $0.169 * * *[0.018]$ & $-0.002[0.083]$ & $-0.009[0.085]$ & $-0.040[0.079]$ \\
\hline Parent MNE local networks (ln) & $0.848 * * *[0.014]$ & $0.848 * * *[0.014]$ & $0.848 * * *[0.014]$ & $0.064[0.103]$ & $0.022[0.088]$ & $0.036[0.098]$ \\
\hline Parent MNE R\&D ratio (\%) & $0.191[0.280]$ & $0.195[0.280]$ & $0.192[0.281]$ & $2.224[1.398]$ & $2.190[1.494]$ & $2.318[1.463]$ \\
\hline Conventional FDI motivation dummies & Yes & Yes & Yes & Yes & Yes & Yes \\
\hline Industry fixed effects & Yes & Yes & Yes & Yes & Yes & Yes \\
\hline Regional fixed effects & Yes & Yes & Yes & Yes & Yes & Yes \\
\hline Yearly fixed effects & Yes & Yes & Yes & Yes & Yes & Yes \\
\hline Number of Observations & 15,777 & 15,777 & 15,777 & 17,788 & 17,788 & 17,788 \\
\hline $\mathrm{R}^{2}$ & 0.4412 & 0.4415 & 0.4412 & & & \\
\hline$\chi^{2}$ & $889,151.60 * * *$ & $899,548.01 * * *$ & $899,104.36^{* * *}$ & $30.52 * * *$ & $26.23 * * *$ & $28.17 * * *$ \\
\hline Number of Instruments & & & & 87 & 87 & 88 \\
\hline Hansen’s J Test ( $p$-value) & & & & $(0.977)$ & $(0.989)$ & $(0.986)$ \\
\hline Difference-in-Hansen Test ( $p$-value) & & & & $(0.871)$ & $(0.559)$ & $(0.572)$ \\
\hline AR(1) Test in Differences ( $p$-value) & & & & $(0.092)$ & $(0.044)$ & $(0.055)$ \\
\hline AR(2) Test in Differences ( $p$-value) & & & & $(0.179)$ & $(0.241)$ & $(0.224)$ \\
\hline
\end{tabular}

Notes. Standard errors in brackets; ${ }^{* * *} p<0.01,{ }^{* *} p<0.05,{ }^{*} p<0.1$, two-tailed tests. 